\title{
Document delivery, cost containment and serial ownership
}

\author{
By Susan B. Ardis \\ Head, McKinney Engineering Library \\ University of Texas at Austin
}

and Karen S. Croneis

Head, Physics Math Astronomy Library

University of Texas at Austin

\section{Price versus pride of ownership.}

B udgetary constraints and uncertain budget allocations are forcing libraries to re-examine strategies for providing patrons with access to serial information. Historically, the most common method or strategy used to provide access in college and research libraries has been to maintain a large serials collection. As a result, at research libraries, serials make up a substantial percentage of the materials budget. UT Austin General Libraries is no exception; scientific and technological serials alone represent $45 \%$ of the total serial budiget. Because of inflation, currency fluctuations and price increases, this portion of the budget continues to increase at rates beyond the control of libraries.

Ownership of serial titles involves more than simply paying an annual subscription price. Additional costs associated with binding, circulation, record-keeping and housing are often overlooked when determining total expenditures for serials. The desire to add new titles, while rarely overlooked, also has an impact because the budget must also increase to accommodate these new titles.

Over the last year the General Libraries have had to reduce serial expenditures by $10 \%$. These recent serial cancellations prompted critical evaluations of the collections in terms of use, price and immediate access. The first to be canceled were duplicated or marginal titles. Unfortunately, in order to meet the cancellation quotas, the library also had to cancel some in-scope but infrequently used materials. For the purposes of this project, a title was considered to be "infrequently used" if it had circulated an average of less than once per year.

Like other academic libraries, the strategy of the General Libraries was to own as many titles as possible and to rely on interlibrary loan (ILL) for outof-scope materials. Since immediate access for these out-of-scope items was not a high priority, interlibrary loan was a viable option. However, as in-scope materials were canceled, access became more important. Because of slow turn-around times, ILL was not considered to be an acceptable option for these canceled in-scope titles.

An option which has been available but not widely considered in academic libraries is the purchase of copies of journal articles from commercial document delivery services rather than subscribing to the journal itself. This alternative had never been investigated at UT for several reasons, including pride of ownership, a centralized interlibrary loan service, and deposit account requirements.

Today's near-crisis situation in journal prices, added to the ever growing pressure of space constraints and budget uncertainties, suggested a new look at this option. The science librarians at UT hypothesized that purchasing articles from commercial document delivery services might be more cost effective than ownership of infrequently used titles. In order to test this hypothesis, a pilot study of selected commercial document delivery systems was conducted from February 2 through April 30, 1987. 


\section{When people rely on you}
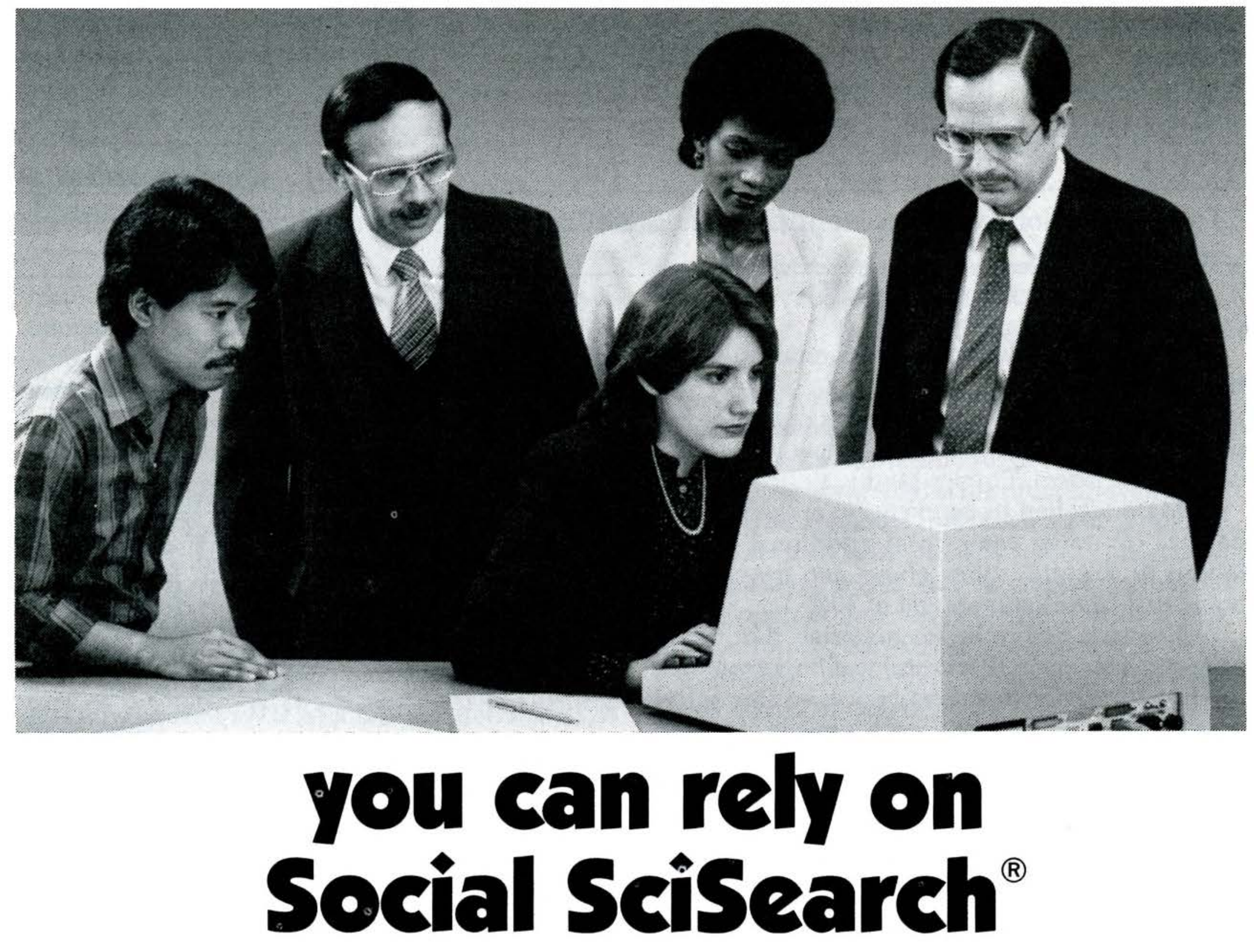

When you're asked to perform a literature search in the social sciences, you can depend on Social SciSearch for coverage and for currency.

Social SciSearch provides full coverage of approximately 1400 journals from the worldwide social sciences literature, plus items relevant to the social sciences from an additional 3300 journals in the natural, physical, and biomedical sciences. And rapid journal processing and frequent updates ensure the currency that Social SciSearch users need.

Social SciSearch is available on DIALOG, BRS, and DIMDI. To find out how you can start searching Social SciSearch, call us toll-free: 800-523-1857. In Pennsylvania, call collect: 215-386-0100, extension 1591.

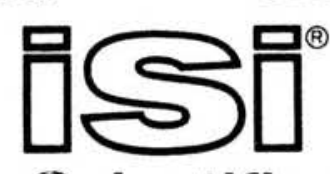

\section{Institute for Scientific Information ${ }^{\circledR}$}

3501 Market Street, Philadelphia, Pennsylvania 19104 U.S.A.

Telephone: (215) 386-0100, Cable: SCINFO, Telex: 84-5305, Telecopier: (215) 386-6362 European Branch: 132 High Street, Uxbridge, Middlesex UB8 1DP, United Kingdom 
TABLE I

Results by Library: All Vendors

\begin{tabular}{lcccr}
\hline \hline Library & $\begin{array}{c}\text { Documents } \\
\text { Ordered }\end{array}$ & $\begin{array}{c}\text { Documents } \\
\text { Received }\end{array}$ & $\begin{array}{c}\text { Not } \\
\text { Available }\end{array}$ & $\begin{array}{c}\text { Total } \\
\text { Cost }\end{array}$ \\
\hline Chemistry & 51 & 42 & 9 & $\$ 575.25$ \\
Engineering & 100 & 100 & 0 & $\$ 1,036.70$ \\
Geology & 1 & 1 & 0 & $\$ 14.00$ \\
Life Science & 52 & 48 & 3 & $\$ 675.25$ \\
Physics-Math & 8 & 5 & 3 & $\$ 56.00$ \\
TOTAL & 212 & $196^{*}$ & 15 & $\$ 2,357.20$ \\
\hline
\end{tabular}

*The first vendor contacted supplied 188 of these documents; the other 8 were supplied by the second vendor.

The following guidelines were established for the test.

1) Requests had to be submitted at one of the five science libraries (Chemistry, Engineering, Geology, Life Sciences, Physics-Math).

2) Materials had to be scientific or technical in nature. (Funding came from additional cancellations of scientific titles above and beyond the mandated cancellation target of $10 \%$.)

3) Requests had to be for materials that the libraries did not own. (Because it was important that this be a test of document delivery as an alternative to ownership, we did not accept requests for materials which were lost, in circulation or at the bindery.)

4) During the test phase documents had to be available from CTIC, Chemical Abstracts (CA), NTIS, or GLOBAL. (These vendors were chosen because of their heavy emphasis on science and technology.)

5) Document receipt, ordering, record-keeping and accounting were centralized. Information was collected on turn-around time, staffing requirements, vendor performance and accuracy, document availability, billing procedures, cost per article and user acceptance of the service.

6) Access to this pilot service was available to all UT students, staff and faculty.

7) Publicity was by referral only due to limited funds and unknown demand.

8) Articles became the property of the requester.

\section{Results}

Results of the study are summarized in Tables $1-3$. Low usage by PMA and Geology was expected and is related to the vendors selected. The proposed addition of other vendors such as UMI, Petroleum Abstracts and AIAA is expected to affect usage distribution. However, it should be noted that some of the collections are stronger than others. The Geology collection, for example, is very strong while the Life Science collection is at a disadvantage because the medical school and its collection are located 75 miles away. Results for Engineering are also somewhat skewed by the addition of NTIS and GLOBAL as vendors because all of these requests originated at the Engineering Library.

\section{Conclusions}

As anticipated, the study confirmed the hypothesis that commercial document delivery of infrequently used materials is a cost-effective alternative to ownership. If only 20 infrequently used journals with an average subscription price of $\$ 200$ per year were cancelled, the resulting savings could be used to purchase 415 articles. Commercial document delivery would provide a method of cost

\section{TABLE II}

Results by Library: Vendors CA, CTIC

\begin{tabular}{lcccr}
\hline \hline Library & $\begin{array}{c}\text { Documents } \\
\text { Ordered }\end{array}$ & $\begin{array}{c}\text { Documents } \\
\text { Received }\end{array}$ & $\begin{array}{c}\text { Not } \\
\text { Available }\end{array}$ & $\begin{array}{c}\text { Total } \\
\text { Cost }\end{array}$ \\
\hline Chemistry & 51 & 42 & 9 & $\$ 575.25$ \\
Engineering & 30 & 30 & - & $\$ 349.00$ \\
Geology & 1 & 1 & - & $\$ 14.00$ \\
Life Science & 52 & 48 & 3 & $\$ 675.25$ \\
Physics-Math & 8 & 5 & 15 & $\$ 56.00$ \\
TOTAL & 142 & 126 & & $\$ 1,669.50$ \\
\hline
\end{tabular}


TABLE III

Results by Vendor

\begin{tabular}{lcccr}
\hline \hline Vendor & $\begin{array}{c}\text { Documents } \\
\text { Ordered }\end{array}$ & $\begin{array}{c}\text { Average } \\
\text { Cost }\end{array}$ & $\begin{array}{c}\text { Total } \\
\text { Cost }\end{array}$ & $\begin{array}{r}\text { Average } \\
\text { Time** }\end{array}$ \\
\hline CA & 69 & $\$ 9.62$ & $\$ 664.00$ & 7.3 \\
CTIC & 68 & $\$ 9.04$ & $\$ 615.00$ & 8.4 \\
GLOBAL & 4 & $\$ 32.50$ & $\$ 130.00$ & 10.2 \\
NTIS & 66 & $\$ 8.45$ & $\$ 557.70$ & 14.4 \\
TOTAL & 207 & $\mathrm{~nm}^{*}$ & $\$ 1,966.60$ & 10.1 \\
\hline \multirow{2}{*}{ not meaningful } & & & \\
${ }^{* *}$ average turn-around time in calendar days
\end{tabular}

containment and information on collection development. In addition, as a long-term strategy, it would offer greater flexibility in space and facilities management.

Increased accountability and improved public relations were two unanticipated results. The decision to decentralize this service rather than enlarge the traditional interlibrary loan function was fortuitous. Users knew where to follow up on their requests, a fact that increased accountability for individual library units. Patron awareness of this service increased dramatically in a short time without any formal publicity. Over half of them expressed the hope that this would become a permanent service.

Another unexpected result occurred because each request was forwarded by reference librarians. In the past, UT staff sent users to a centralized interlibrary loan office and as a result staff had no further contact with the patron. Both users and reference staff came to view document delivery as an extension of the reference process. Although patrons usually make this connection in special libraries it is rarely made in academic libraries.

Another benefit of the study involved staff and user morale. The addition of document delivery service gave the staff something positive to offer patrons during the cancellation project. In turn, users did not feel obligated to campaign for retention of specific low-use titles slated for cancellation.

The science librarians have now suggested to the library administration that this service be continued and expanded. One proposal is the establishment of ongoing document delivery funds for each unit. These would be created by the cancellation of additional lesser-used titles. An important component of this proposal is that each library would determine the size of the fund, monitor the fund balance and be responsible for authorizing expenditures.

This test successfully demonstrates that document delivery is cost effective. It can control costs, provide timely access, and give the library something positive to offer during difficult times. Document delivery is an attractive alternative to ownership.

\section{RBMS Preconference in New Orleans}

ACRL's 29th Rare Books and Manuscripts Preconference in New Orleans, July 5-8, 1988, will focus on the relationship between special collections libraries and the museum world and what they can learn from each other. Topics to be examined will include public programs, fundraising, access and cataloging, collection development and reference services in a museum library, the scholar's perspective, and institutional perspectives of archives, libraries, and historical societies.

The speakers will include: William Cagle, director of the Lilly Library, University of Indiana; Werner Gundersheimer, director of the Folger Shakespeare Library; Nancy Gwinn, assistant director for collections management, Smithsonian Institution Libraries; Anthony P. Harvey, coordinator of planning and development at the British Museum (Natural History); and Deirdre Stam, School of Information Studies, Syracuse University.

To complement the plenary sessions, the RBMS Continuing Education Committee is planning a variety of seminars on topics related to the theme of the preconference. There will also be visits to Tulane University and to Louisiana State University in Baton Rouge. Further information on the seminars and program will be provided in the registration brochure, which will be available in March. The brochure will also include a full schedule of events that will run until 3:30 p.m. on Friday, July 8 .

The preconference hotel will be the Royal Orleans in the French Quarter. Rates will be $\$ 65$ for single, double, or twin; $\$ 20$ additional for a third person. These rates will be honored throughout ALA Annual Conference.

The Program Committee consists of Ann Gwyn (chair), Robert Martin (local arrangements), John Y. Cole, Ellen Dunlap, Joan Friedman, Barbara Paulson, and Alice Schreyer. 